\title{
Identification key for anuran amphibians in a protected area in the northeastern Atlantic Forest
}

\author{
Marcos Jorge Matias Dubeux ${ }^{1,2,3,}$; Filipe Augusto Cavalcanti do Nascimento ${ }^{2,3,5} ;$ Ubiratan Gonçalves ${ }^{2,3,6}$ \& Tamí Mott ${ }^{2,3,7}$
}

1 Universidade Federal de Pernambuco (UFPE), Centro de Biociências (CB), Departamento de Zoologia, Laboratório de Herpetologia (LHERP), Programa de Pós-Graduação em Biologia Animal (PPGBA). Recife, PE, Brasil.

${ }^{2}$ Universidade Federal de Alagoas (UFAL), Instituto de Ciências Biológicas e da Saúde (ICBS), Laboratório de Biologia Integrativa (LABI). Maceió, AL, Brasil.

${ }^{3}$ Universidade Federal de Alagoas (UFAL), Museu de História Natural (MHN), Setor de Herpetologia. Maceió, AL, Brasil.

${ }^{4}$ ORCID: http://orcid.org/0000-0003-3049-1720.E-mail: marcosdubeux.bio@gmail.com (corresponding author)

${ }^{5}$ ORCID: http://orcid.org/0000-0002-1684-3753. E-mail: filipe.nascimento@mhn.ufal.br

${ }^{6}$ ORCID: http://orcid.org/0000-0003-2076-9063. E-mail: ugsbogertia@gmail.com

${ }^{7}$ ORCID: http://orcid.org/0000-0002-5896-4780. E-mail: tamimott@hotmail.com

\begin{abstract}
The identification of anuran amphibians is still a challenge in megadiverse assemblages. In the Neotropics, the Atlantic Forest harbors more than 600 anuran species, and many studies in this ecoregion report anuran assemblages surpassing 30 species. Taxonomic keys facilitate the identification of biological diversity, however only a few are available for anuran assemblages in the Atlantic Forest. Herein we present an identification key for 40 anuran species distributed across 20 genera and nine families, occurring in the Environmental Protection Area of Catolé and Fernão Velho, northeastern Atlantic Forest. Thirty-five morphological characteristics were used in the key, all of which can be easily observed in living and museum specimens. This pioneer study provides the first identification key for an amphibian assemblage in the northeastern Atlantic Forest and this baseline information acts as the starting point for the development of evolutionary and ecological research in this conservation unit.
\end{abstract}

Keywords. Conservation Unit; Hotspot; Environmental Protection Area of Catolé and Fernão Velho; Dichotomous key; Taxonomic key.

\section{INTRODUCTION}

To accurately identify a species, the first step is to assess the diversity of an area, which acts as the baseline for further ecological and evolutionary studies (e.g., Narvaes \& Rodrigues, 2009; Pereyra et al., 2016). Furthermore, species lists can be used for conservation purposes (ICMBio, 2018). The correct identification of a species can be facilitated when taxonomic keys are available. These tools use the diagnostic characteristics of species to guide the user, whose goal is to identify the lowest hierarchical level to which that individual belongs.

The identification of anuran amphibians in megadiverse assemblages is very challenging (Fouquet et al., 2007a; Cassini et al., 2013; Peloso et al., 2014, 2018; Taucce et al., 2018). Anurans display a great morphological similarity between species and cryptic species (those marked by pronounced morphological conservatism) are com- monly found in this group (Camargo et al., 2006; Fouquet et al., 2007a, 2007b; Walker et al., 2018; Taucce et al., 2018). Additionally, the imprecise diagnostic characteristics for some species, along with a plethora of polymorphic traits hamper the accurate diagnosis of many taxa.

Despite the importance of taxonomic keys in facilitating the identification of biological diversity, these tools are still a greatly lacking for Neotropical anurans. For example, the Brazilian Atlantic Forest ecoregion harbors over 600 anuran species (Rossa-Feres et al., 2017), and currently there are only six available identification keys for adult anurans that are published in books or scientific journals (Eterovick \& Sazima, 2004 for Serra do Cipó, Minas Gerais state; Loebmann, 2005 for the coastal region of southernmost Brazil, Rio Grande do Sul state; Ribeiro et al., 2005 for the Serra do Japí, São Paulo state; Kwet et al., 2010 for the Serra Gaúcha, Rio Grande do Sul state; Provete et al., 2011 for the northwest region of São Paulo 

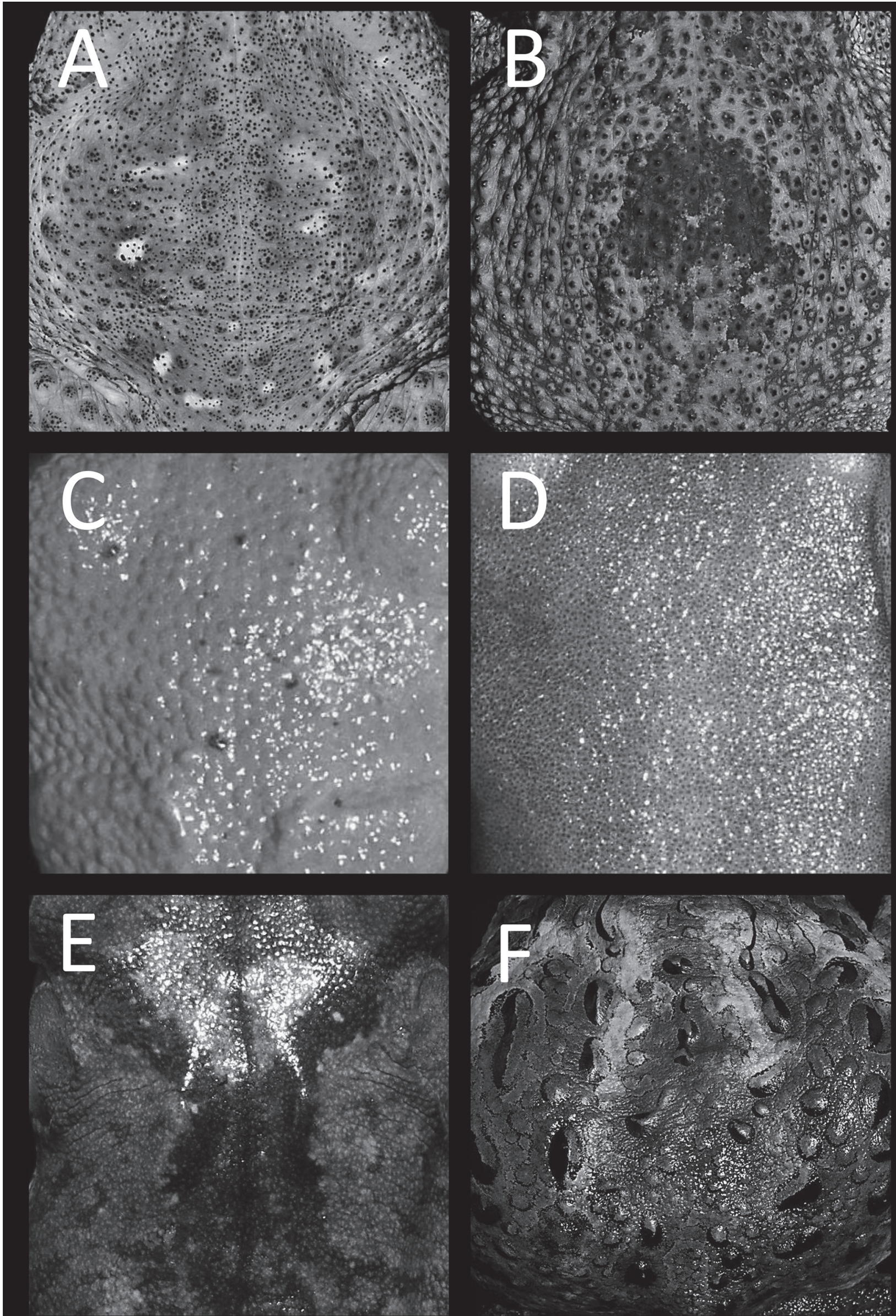

Figure 1. Discrete characters used in the identification key for the anuran amphibians occurring in the Environmental Protection Area of Catolé and Fernão Velho, Alagoas state, northeastern Brazil. Dorsal skin texture. (A) warty; (B) spiculate; (C) granular; (D) smooth; (E) shagreened; (F) tubercular. 
state; and Pimenta et al., 2014 for the municipalities of Alvorada de Minas, Conceição do Mato Dentro and Dom Joaquim, Minas Gerais state). All these keys include anuran assemblages from the southern part of Atlantic Forest.

The aim of the present study was to develop an identification key for 40 anuran species occurring in the Environmental Protection Area of Catolé and Fernão Velho in the northeastern Atlantic Forest of Brazil.

\section{MATERIAL AND METHODS}

The elaboration of identification keys was based on adult anurans obtained in the Environmental Protection Area of Catolé and Fernão Velho (EPACFV), a conservation unit in the Northeastern Atlantic Forest. The area covers $37.12 \mathrm{~km}^{2}$ and presents a mosaic of phytophysiognomies that vary from ombrophylous forest to mangroves (sensu Assis, 2000; Oliveira et al., 2014). All specimens were collected from 1994 to 2018 and are housed in the Herpetological Collection of the Museu de História Natural da Universidade Federal de Alagoas (MUFAL; Appendix 1).

The discrete characteristics followed the nomenclature proposed or modified from Myers \& Duellman (1982), Heyer et al. (1990), Kwet \& Di-Bernardo (1999), Kok \& Kalamandeen (2008) and Napoli \& Pimenta (2009). All specimens were analyzed using a Coleman ${ }^{\circ}$ NSZ 405 stereomicroscope. Additionally, the available literature for each species description was used.

The identification key was designed to separate species groups in a taxonomically inclusive manner, includ- ing family and genus level terminals wherever possible. The taxonomic nomenclature followed the current phylogenetic proposals (e.g., Faivovich et al., 2005; De-Sá et al., 2014; Duellman et al., 2016). The key was tested by people with varying degrees of knowledge on anuran morphology, ranging from undergraduate biology students (not familiar with herpetology) to expert taxonomists of this group.

\section{RESULTS AND DISCUSSION}

A total of 280 adult specimens from 40 species of 20 genera and nine families of anurans (Appendix 1) were obtained from EPACFV (Dubeux et al., 2020). Hylidae was the richest family with 19 species followed by Leptodactylidae (nine spp.), Bufonidae (four spp.), Microhylidae and Phyllomedusidae (two spp. each), Aromobatidae, Craugastoridae, Hemiphractidae and Odontophrynidae (one species each; Dubeux et al., 2020).

Thirty-five morphological characteristics were used in the key, as follows: 14 related to the presence/absence of structures, five related to shape, six related to proportion (size), nine related to color patterns, and one related to skin texture. The characteristics used can be easily observed in both living individuals or preserved specimens and apply to both sexes. Some of these traits may vary with ontogeny and defining characteristics were determined for adult individuals and thus, may not be easily applicable to juvenile individuals. Species terminals are highlighted in bold.

\section{Taxonomic key for the anuran amphibians of Environmental Protection Area of Catolé and Fernão Velho, Alagoas state, northeastern Brazil}

1a. Dorsum showing a warty or spiculate texture (Fig. 1A-B) Bufonidae 2

1b. Dorsum showing a smooth, tubercular, shagreened or granular texture (Fig. 2C-F)

2a. (1a) Parotoid gland evident (Fig. 2A-white arrow); belly and digits showing homogeneous coloration hinella Fitzinger, 18263

2b. Parotoid gland not evident; yellowish-orange color distributed in points on the ventral portion of the thighs and on the most proximal digits.

Frostius pernambucensis (Bokermann, 1962)

3a. (2a) Square shaped snout in ventral view, extends past the end of the lower jaw (Fig. 2B); strongly keratinized cephalic crests.....

Rhinella granulosa (Spix, 1824)

3b. Rounded shaped snout in ventral view, does not extend past the end of the lower jaw (Fig. 2C); poorly keratinized or non-keratinized cephalic crests ... 4

4a. (3b) Paracnemic gland present (Fig. 2A-black arrow); forearm and external foot glands developed; parotoid gland triangular-shape (Fig. 2D) .....

Rhinella diptycha (Cope, 1862)

4b. Paracnemic, forearm and external feet glands absents; parotoid gland elliptical/elongate-shape (Fig. 2E) ....... Rhinella crucifer (Wied-Neuwied, 1821)

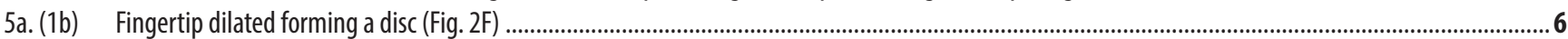

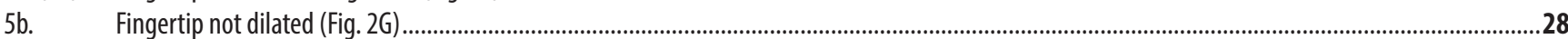

6a. (5a) Presence of a black lateral band extending from the snout to the inguinal region (Fig. 2H)................ Aromobatidae: Allobates olfersioides (Lutz, 1925)

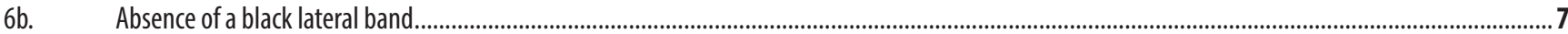

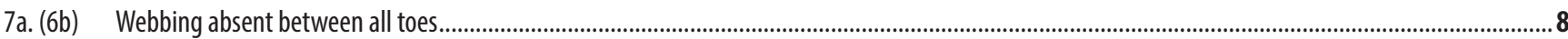

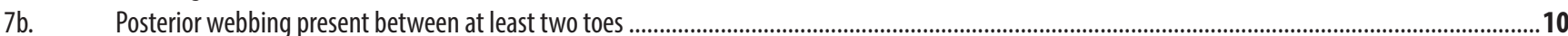

8a. (7a) Head shape longer than wide; pointed snout in dorsal view (Fig. 2l); dark band on supratympanic fold ....................................................................... ..Craugastoridae: Pristimantis ramagii (Boulenger, 1888)

8b. Head shape wider than long; rounded or square snout in dorsal view (Fig. 2B or 2C); dark band on supratympanic fold absent........... Phyllomedusidae 9

9a. (8b) Toe ll shorter than toe I (Fig. 2J).......................................................................................................... Pithecopus gonzagai Andrade et al., 2020

9b. Toe ll longer than toe I. Hylomantis granulosa (Cruz, 1989) 


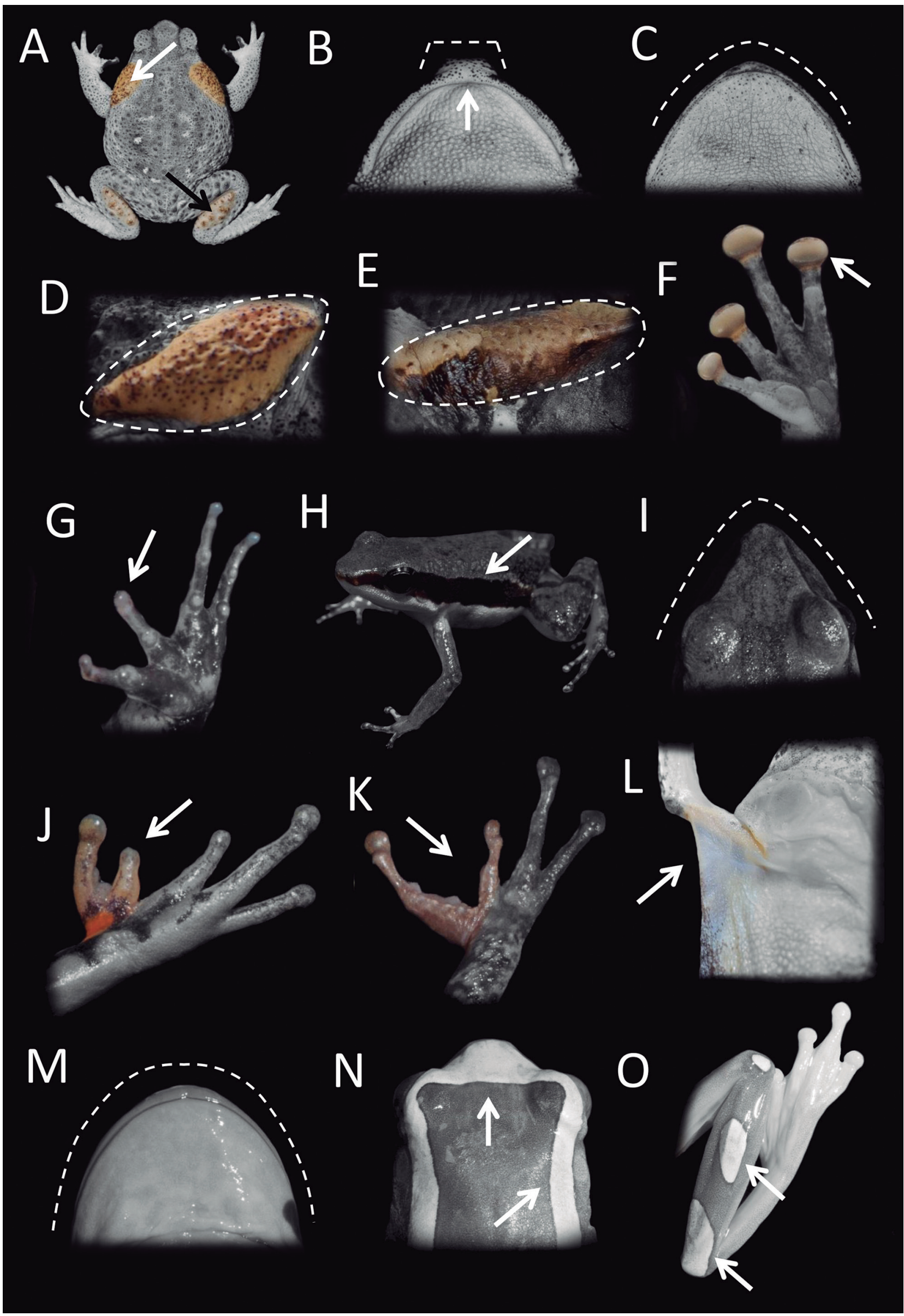

Figure 2. Discrete characters used in the identification key for the anuran amphibians occurring in the Environmental Protection Area of Catolé and Fernão Velho, Alagoas state, northeast Brazil. The details of characters are mentioned in the taxonomic key. 
10a. (7b) Finger I longer than finger III (Fig. 2K).

Hemiphractidae: Gastrotheca fissipes (Boulenger, 1888)

10b. Finger I shorter than finger III

11a. (10b) Axillary membrane present (Fig. 2L)

11b. Axillary membrane absent.

12a. (11a) Rounded shaped snout in dorsal view (Fig. 2C); tympanum diameter smaller than third finger disc diameter

12b. Semicircular snout shape in dorsal view (Fig. 2M); tympanum diameter larger than third finger disc diameter.

Dendropsophus Fitzinger, 184313

..Trachycephalus mesophaeus (Hensel, 1867)

13a. (12a) A light colored band anteriorly delimited from the snout to the intraorbital region and extending laterodorsally (Fig. 2N) ........................................14

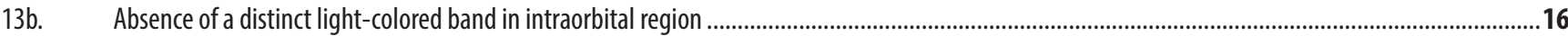

14a. (13a) Presence of light-colored spots on the dorsal surface of the thighs (Fig. 20); light-colored dorsolateral bands joining in the posterior portion of the body

Dendropsophus elegans (Wied-Neuwied, 1824)

14b. Absence of light-colored spots on the dorsal surface of the thighs; light-colored dorsolateral bands do not come together .........................................15

15a. (14b) A distinct laterodorsal light-colored band extending to inguinal region (Fig. 3A)

Dendropsophus oliveirai (Bokermann, 1963)

15b. A distinct laterodorsal light-colored band extending to the mid body (Fig. 3B)

Dendropsophus haddadi (Bastos \& Pombal, 1996)

16a. (13b) Presence of distinct white spot in suborbital region (Fig. 3C); distinct dorsal and dorsolateral coloration clearly delimited .....

Dendropsophus branneri (Cochran, 1948)

16b. Absence of distinct white spot in suborbital region; similar dorsal and dorsolateral coloration

17a. (16b) Presence of discrete ulnar and carpal dermal fringe (Fig. 3D).

17b. Absence of ulnar and carpal dermal fringe.

Dendropsophus soaresi (Caramaschi \& Jim, 1983)

18a. (11b) Protruding snout in lateral view (Fig. 3E)........

Dendropsophus minutus (Peters, 1872)

18b. Rounded or truncated snout in lateral view (Fig. 3F or 3G)

. Ololygon skuki (Lima, Cruz, \& Azevedo, 2011)

19a. (18b) Palmar tubercle absent

Boana Gray, 182520

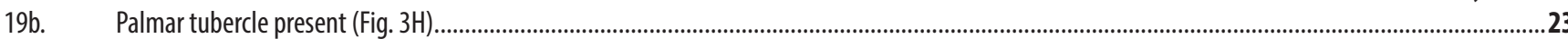

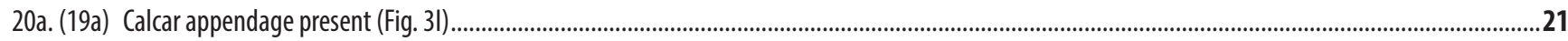

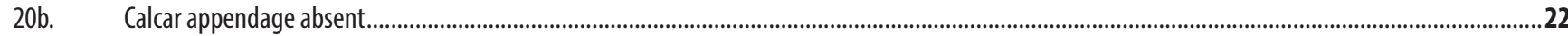

21a. (20a) Sub-cloacal fold and prepolex absent....

21b. Sub-cloacal fold and prepolex present (Fig. 3J)

22a. (20b) Marked supratympanic fold extending to axillary region (Fig. 3k)

22b. Unmarked supratympanic fold extending posteriorly (Fig. 3L).

23a. (19b) Calcar appendage present (Fig. 3l)

Boana semilineata (Spix, 1824)

Boana albomarginata (Spix, 1824)

Boana crepitans (Wied-Neuwied, 1824)

Boana atlantica (Caramaschi \& Velosa, 1996) Scinax nebulosus (Spix, 1824)

23b. Calcar appendage absent . .24

24a. (23b) Pointed-snout in dorsal view (Fig. 2l); a light-colored band anteriorly delimited on the intraorbital region and extending laterodorsally..

Scinax auratus (Wied-Neuwied, 1821)

24b. Rounded snout in dorsal view (Fig. 2C); absence of a distinct light-colored band on the intraorbital region .............................................................25

25a. (24b) Tympanic annulus distinct (Fig. 3M)

25b. Tympanic annulus indistinct (Fig. 3N)

..Phyllodytes edelmoi Peixoto, Caramaschi \& Freire, 2003

26a. (25a) Presence of marbled spots on inguinal region and lateral of thighs (Fig. 30)

26b. Absence of marbled spots on inguinal region and lateral of thighs.

Scinax eurydice (Bokermann, 1968)

27a. (26a) Pigmented ventral region (Fig. 4A); tympanum diameter larger than third finger disc diameter; snout length less than half of head length

Scinax fuscovarius (Lutz, 1925)

27b. Unpigmented ventral region (Fig. 4B); tympanum diameter smaller than third finger disc diameter; snout length larger than half of head length

Scinax x-signatus (Spix, 1824)

28a. (5b) Posterior webbing present between at least two toes; finger I shorter than finger II. Microhylidae 29

28b. Webbing absent between all toes; finger I longer than finger II .. .30

29a. (28a) Presence of a post-cephalic fold projected anteriorly (Fig. 4C); interorbital distance is half the width of the body in the region of the forelimbs

Dermatonotus muelleri (Boettger, 1885)

29b. Absence of post-cephalic fold; interorbital distance similar to the width of the body in the region of the forelimbs

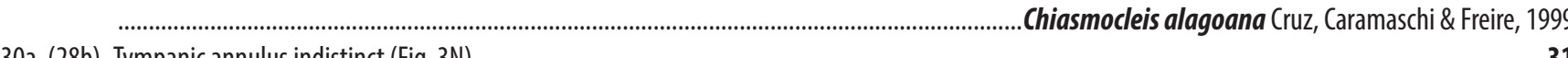

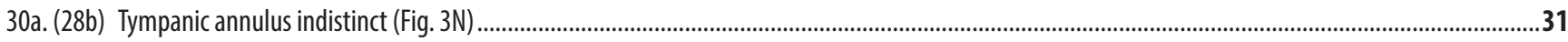

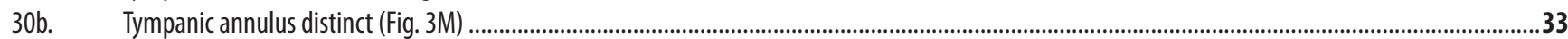

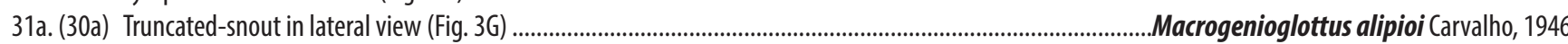

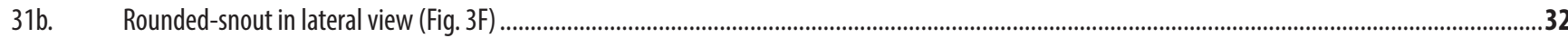

32a. (31b) Supratympanic fold extending halfway down the body ventrally limited by a dark band (Fig. 4D)..........................Physalaemus cuvieri Fitzinger, 1826

32b. Supratympanic fold and lateral dark band absent ...............................................................................Pseudopaludicola mystacalis (Cope, 1887)

33a. (30b) Presence of longitudinal dorsal crests, extending from the supratympanic region to the inguinal region (Fig. 4E and 4F) ...........................................34

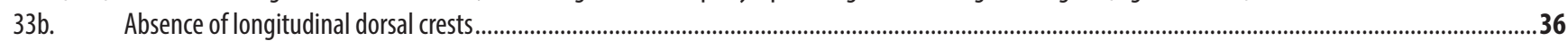

34a. (33a) Only one pair of longitudinal crests willing dorsolaterally (Fig. 4E); black band extending laterally from the tip of the snout to the posterior region of the tympanum

...Leptodactylus mystaceus (Spix, 1824)

34b. More than one pair of longitudinal crests willing in back (Fig. 4F); no black band on the snout

35a. (34b) Pointed-snout in lateral view (Fig. 4G); dark interorbital spot in inverted triangle shape

Leptodactylus fuscus (Schneider, 1799) 


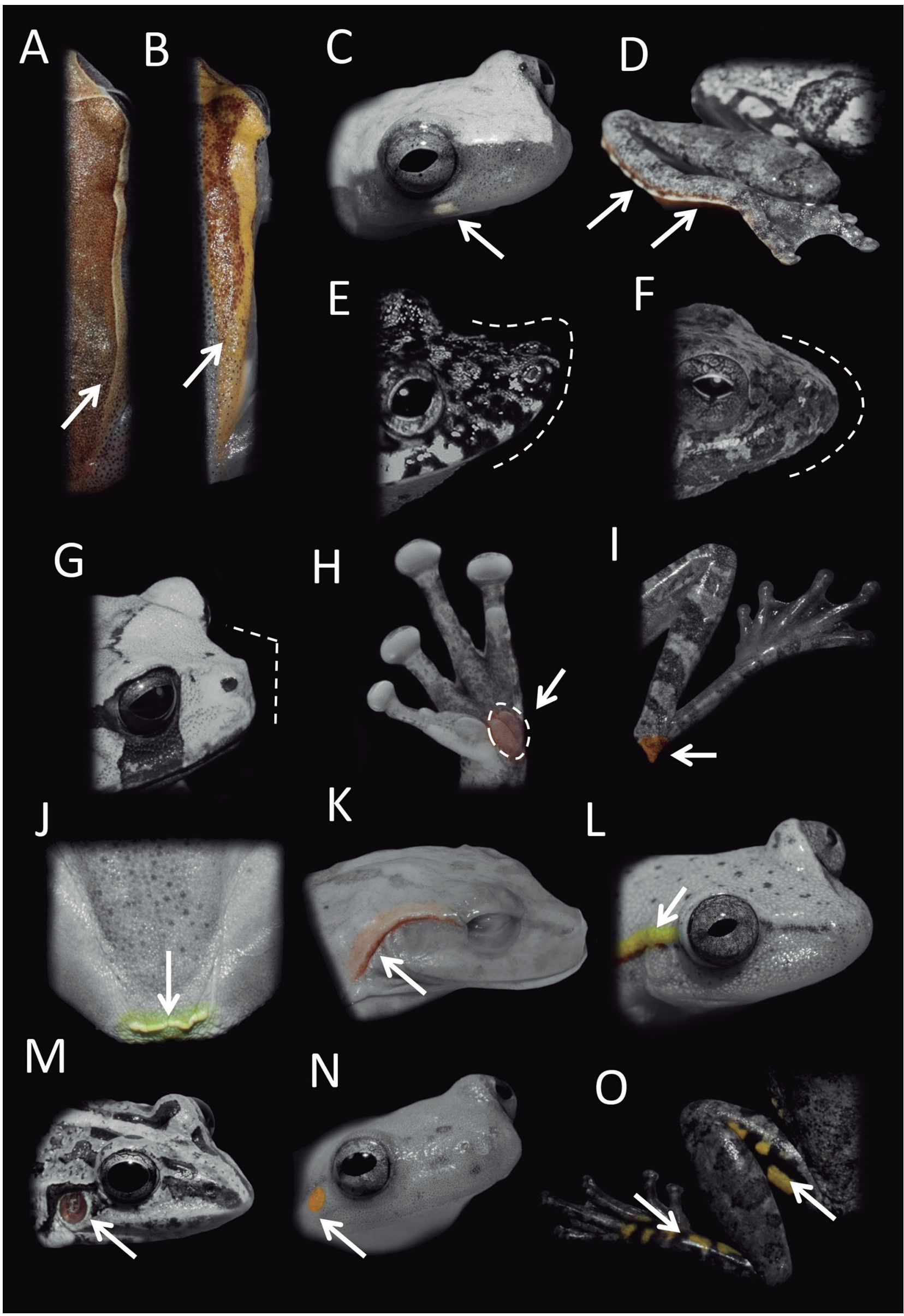

Figure 3. Discrete characters used in the identification key for the anuran amphibians occurring in the Environmental Protection Area of Catolé and Fernão Velho, Alagoas state, northeast Brazil. The details of characters are mentioned in the taxonomic key. 
35b. Rounded-snout in lateral view (Fig. 3F); dark interorbital spot absent

...Leptodactylus macrosternum Miranda-Ribeiro, 1926

36a. (33b) Presence of marbled spots on gular and pectoral regions (Fig. 4H).

36b. Absence of marbled spots on gular and pectoral regions (Fig. 4l) .38

37a. (36a) Reddish coloration on lateral thigh and inguinal region (Fig. 4J).

37b. Indistinct coloration on lateral thigh and inguinal region

Leptodactylus vastus Lutz, 1930 inguinal region (Fig. 4K)

.Adenomera hylaedactyla (Cope, 1868)

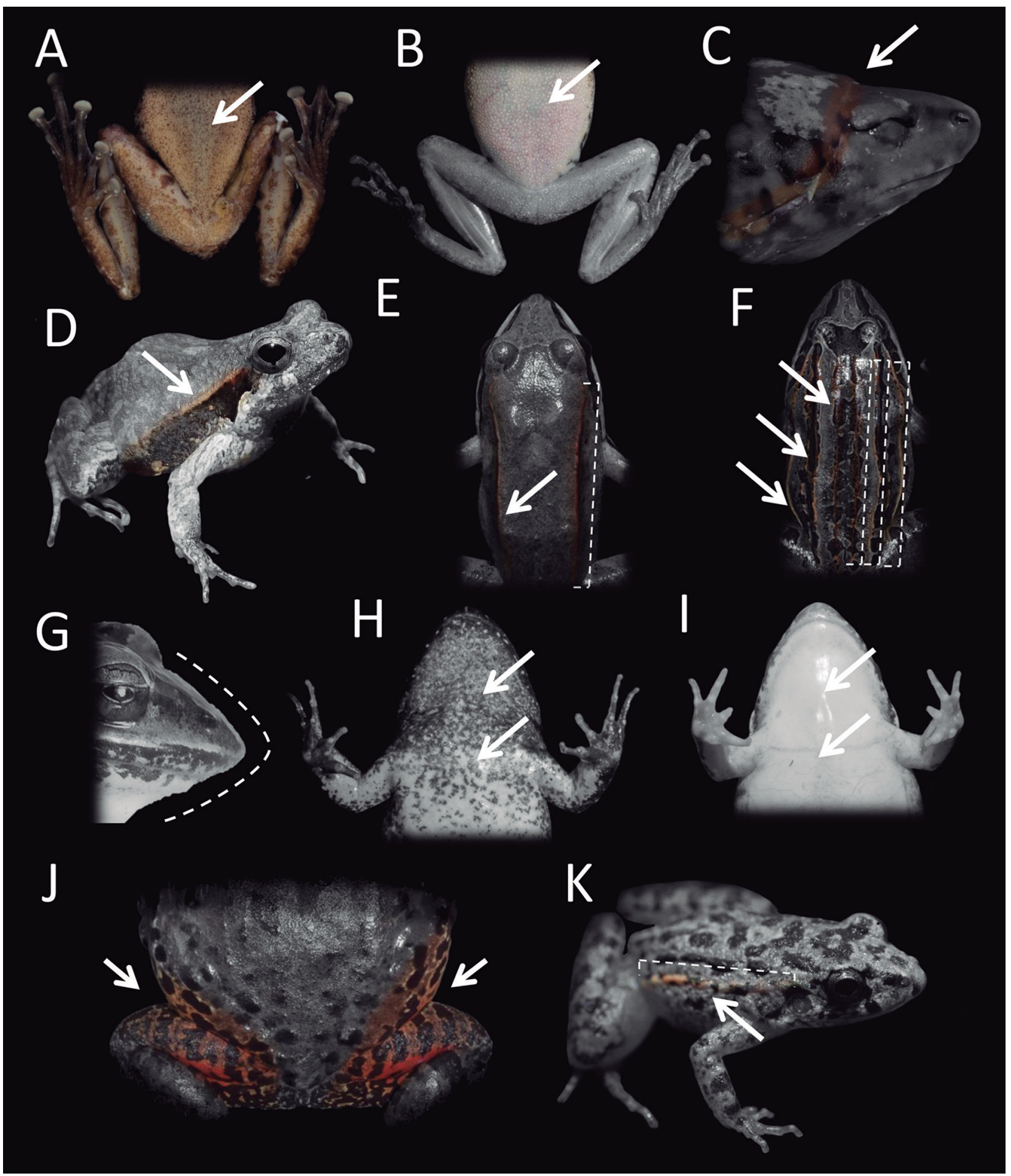

Figure 4. Discrete characters used in the identification key for anuran amphibians occurring in the Environmental Protection Area of Catolé and Fernão Velho, Alagoas state, northeastern Brazil. The details of characters are mentioned in the taxonomic key. 
The Environmental Protection Area of Catolé and Fernão Velho contain important forest remnants in the state of Alagoas. Of the 40 species recorded, three are topotypical of this conservation unit (Chiasmocleis alagoana, Phyllodytes edelmoi and Ololygon skuki), four are currently considered threatened (Allobates olfersioides, Chiasmocleis alagoana, Hylomantis granulosa, and Ololygon skuki) and one species are lacking sufficient data for the assessment of their threatened status (Gastrotheca fissipes; Dubeux et al., 2020). This area represents one of the few forest remnants of the northeastern Atlantic Forest, with a long term herpetofauna survey and approximately 26 years of research led by different researchers.

This pioneer study provides the first identification key for an anuran assemblage in the northeastern Atlantic Forest. This study will certainly facilitate the identification of anurans in this Environmental Protection Area. Moreover, this baseline information can act as a starting point for the development of evolutionary and ecological research as well as providing a framework for the improved management of the fauna found in this conservation unit.

\section{ACKNOWLEDGMENTS}

The authors thank the Museu de História Natural da Universidade Federal de Alagoas for their support in research and the availability of material for studies; to the researchers L. Lima, J. Almeida, L. Correia, G. Rodrigues, I. Santos, B. Lisboa, A. Valencia-Aguilar, G. Ruano-Fajardo, E. Freire, M. Lima, N. Vieira, K. Vieira and G. Skuk (in memoriam) who through their commitment and dedication help and/or aid in the advancement of amphibian knowledge in the Alagoas state; to the Batalhão de Polícia Ambiental do Estado de Alagoas for the support in the field trips; MANEFAU LTDA., Instituto do Meio Ambiente do Estado de Alagoas, MJMD thanks FACEPE (IBPG-1117-2.04/19) and TM thanks CNPq (309904/2015-3 and 312291/2018-3) and FAPEAL for assistance in research and financial support.

\section{AUTHORS' CONTRIBUTIONS}

Conceived and designed the project: MJMD, FACN, UG, TM. Collected field samples: MJMD, FACN, UG. Analyzed the data: MJMD, FACN, UG, TM. Species identification: MJMD. Wrote the paper: MJMD, FACN, UG, TM. All authors read and approved the final version of the manuscript.

\section{REFERENCES}

Assis, J.S. 2000. Biogeografia e conservação da biodiversidade: projeções para Alagoas. Maceió, Catavento. 200p.

Camargo, A.; De-Sá, R.0. \& Heyer, W.R. 2006. Phylogenetic analyses of mtDNA sequences reveal three cryptic lineages in the widespread neotropical frog Leptodactylus fuscus (Schneider, 1799) (Anura, Leptodactylidae). Biological Journal of the Linnean Society, 87(2): 325-341. DOI

Cassini, C.S.; Orrico, V.G.D.; Dias, I.R.; Solé M. \& Haddad, C.F.B. 2013. Phenotypic variation of Leptodactylus cupreus Caramaschi, São-Pedro \& Feio, 2008 (Anura, Leptodactylidae). Zootaxa, 3616: 73-84. DOI

De-Sá, R.0.; Grant, T.; Camargo, A.; Heyer, W.R.; Ponssa, M.L. \& Stanley, E. 2014. Systematics of the neotropical genus Leptodactylus Fitzinger, 1826 (Anura: Leptodactylidae): phylogeny, the relevance of non-molecular evidence, and species accounts. South American Journal of Herpetology, 9(s1). DOI

Dubeux, M.J.M.; Gonçalves, U.; Nascimento, F.A.C. \& Mott, T. 2020. Anuran amphibians of a protected area in the Northern Atlantic Forest with comments on topotypic and endangered populations. Herpetology Notes, 13:61-74.

Duellman, W.E.; Marion, A.B. \& Hedges, S.B. 2016. Phylogenetics, classification, and biogeography of the treefrogs (Amphibia: Anura: Arboranae). Zootaxa, 4104(1): 1-109. DOI

Eterovick, P.C. \& Sazima, I. 2004. Anfíbios da Serra do Cipó: Minas Gerais, Brasil. Belo Horizonte, Editora PUC Minas. 152p.

Faivovich, J.; Haddad, C.F.; Garcia, P.C.; Frost, D.R.; Campbell, J.A. \& Wheeler, W.C. 2005. Systematic review of the frog family Hylidae, with special reference to Hylinae: phylogenetic analysis and taxonomic revision. Bulletin of the American Museum of Natural History, 2005(294): 1-240.DOI

Fouquet, A.; Gilles, A.; Vences, M.; Marty, C.; Blanc, M. \& Gemmell, N.J. 2007 a. Underestimation of species richness in Neotropical frogs revealed by mtDNA analyses. Plos One, 2(10): e1109. DOI

Fouquet, A.; Vences, M.; Salducci, M.D.; Meyer, A.; Marty, C.; Blanc, M. \& Gilles, A. 2007b. Revealing cryptic diversity using molecular phylogenetics and phylogeography in frogs of the Scinax ruber and Rhinella margaritifera species groups. Molecular phylogenetics and Evolution, 43(2): 567-582.

Heyer, W.R.; Rand, A.S.; Da-Cruz, C.A.G.; Peixoto, O.L. \& Nelson, C.E. 1990. Frogs of Boracéia. Arquivos de Zoologia, São Paulo, 31(4): 231-410.

Instituto Chico Mendes de Conservação da Biodiversidade (ICMBio). 2018. Fauna brasileira ameaçada de extinção. In: Fauna brasileira ameaçada de extinção. Brasília, Fundação Biodiversitas para a Conservação da Diversidade Biológica. 492p.

Kok, P.J. \& Kalamandeen, M. 2008. Introduction to the taxonomy of the amphibians of Kaieteur National Park, Guyana. Brussels, Koninklijk Belgisch Instituut voor Natuurwetenschappen. 289p. (ABC Taxa, 5).

Kwet, A. \& Di-Bernardo, M. 1999. Pró-Mata - Anfibios, Amphibien, Amphibians. Porto Alegre, EDIPUCRS. 148p.

Kwet, A.; Lingnau, R. \& Di-Bernardo, M. 2010. Pró-Mata: Anfíbios da Serra Gaúcha, Sul do Brasil. 2.ed. Tübingen, Brasilien-Zentrum de Universität Tübingen, and Porto Alegre, EDIPUCRS. 148p.

Loebmann, D. 2005. Os anfibios da região costeira do extremo sul do Brasil: guia ilustrado. Pelotas, USEB. 76p. (Coleção Manuais de Campo USEB, n. 4).

Myers, C.W. \& Duellman, W.E. 1982. A new species of Hyla from Cerro Colorado, and other tree frog records and geographical notes from western Panama. American Museum Novitates, 2752:1-32.

Napoli, M.F. \& Pimenta, B.V. 2009. A new species of the Bokermannohyla circumdata group (Anura: Hylidae) from the coastal forests of Bahia, Northeastern Brazil. Copeia, 2009(4): 674-683. DOI

Narvaes, P. \& Rodrigues, M.T. 2009. Taxonomic revision of Rhinella granulosa species group (Amphibia, Anura, Bufonidae), with a description of a new species. Arquivos de Zoologia, 40: 1-73. DOI

Oliveira, A.N.S.; Amorim, C.M.F. \& Lemos, R.P.L. 2014. As riquezas das áreas protegidas no território alagoano. Maceió, Instituto do Meio Ambiente do Estado de Alagoas, Mineração Vale Verde.

Peloso, P.L.; De-Oliveira, R.M.; Sturaro, M.J.; Rodrigues, M.T.; Lima-Filho, G.R.; Bitar, Y.O. \& Aleixo, A. 2018. Phylogeny of Map Tree Frogs, Boana 
semilineata Species Group, with a New Amazonian Species (Anura: Hylidae). South American Journal of Herpetology, 13(2): 150-170. D0I

Peloso, P.L.; Sturaro, M.J.; Forlani, M.C.; Gaucher, P.; Motta, A.P. \& Wheeler, W.C. 2014. Phylogeny, taxonomic revision, and character evolution of the genera Chiasmocleis and Syncope (Anura, Microhylidae) in Amazonia, with descriptions of three new species. Bulletin of the American Museum of Natural History, 386(1): 1-112. D0I

Pereyra, M.0.; Baldo, D.; Blotto, B.L.; Iglesias, P.P.; Thomé, M.T.; Haddad, C.F.; Barrio-Amoros, C.; Ibánez, R. \& Faivovich, J. 2016. Phylogenetic relationships of toads of the Rhinella granulosa group (Anura: Bufonidae): a molecular perspective with comments on hybridization and introgression. Cladistics, 32(1): 36-53. DOI

Pimenta, B.; Costa, D.; Murta-Fonseca, R. \& Pezzuti, T. 2014. Anfíbios Alvorada de Minas - Conceição do Mato Dentro - Dom Joaquim. Bicho do Mato Editora, Belo Horizonte, Minas Gerais.

Provete, D.B.; Garey, M.V.; Silva, F.R.D. \& Rossa-Feres, D.D.C. 2011. Anurofauna do noroeste paulista: lista de espécies e chave de identificação para adultos. Biota Neotropica, 11(2): 377-391. D01
Ribeiro, R.D.S.; Egito, G.T.B.T.D. \& Haddad, C.F.B. 2005. Chave de identificação: anfíbios anuros da vertente de Jundiaí da Serra do Japi, Estado de São Paulo. Biota Neotropica, 5(2): 235-247. DOI

Rossa-Feres, D.C.; Garey, M.V.; Caramaschi, U.; Napoli, M.F.; Nomura, F.; Bispo, A.; Brasileiro, C.A.; Thome, M.T.C.; Sawaya, R.J.; Conte, C.E.; Cruz, C.A.; Nascimento, L.B.; Gasparini, J.L.; Almeida, N.P. \& Haddad, C.F.B. 2017. Anfíbios da Mata Atlântica: lista de espécies, histórico dos estudos, biologia e conservação. In: Filho, E.L.A.M. \& Conte, C.E. (Eds.). Revisões em Zoologia: Mata Atlântica. Curitiba, Editora UFPR. p. 237-314.

Taucce, P.P.; Canedo, C.; Parreiras, J.S.; Drummond, L.0.; Nogueira-Costa, P. \& Haddad, C.F; 2018. Molecular phylogeny of Ischnocnema (Anura: Brachycephalidae) with the redefinition of its series and the description of two new species. Molecular Phylogenetics and Evolution, 128: 123-146. DOI

Walker, M.; Lyra, M.L. \& Haddad, C.F. 2018. Phylogenetic relationships and cryptic species diversity in the Brazilian Egg-Brooding tree frog, genus Fritziana Mello-Leitão 1937 (Anura: Hemiphractidae). Molecular Phylogenetics and Evolution, 123: 59-72. D0I 
APPENDIX 1

\section{Specimens examined.}

\section{AROMOBATIDAE}

Allobates olfersioides: $(n=9)$ MUFAL 2325-26, 2684, 2687, 14148, 14183, 14192, 14195, 14250.

\section{BUFONIDAE}

Frostius pernambucensis: $(\mathrm{n}=4)$ MUFAL 4273, 4278, 8048, 14262.

Rhinella crucifer: $(\mathrm{n}=1)$ MUFAL14189.

Rhinella granulosa: $(\mathrm{n}=12)$ MUFAL 3105, 3999, 8130, 14218-24, 14226-27.

Rhinella dypticha: $(\mathrm{n}=4)$ MUFAL 14172, 14179-80, 14266.

\section{CRAUGASTORIDAE}

Pristimantis ramagii: $(\mathrm{n}=9)$ MUFAL 2773-74, 7823, 8015, 14168, 14212, 14216-17, 14228.

\section{HEMIPHRACTIDAE}

Gastrotheca fissipes: ( $n=6)$ MUFAL 4675, 5488, 14191, 14209, 14242, 14260.

\section{HYLIDAE}

Boana albomarginata: $(\mathrm{n}=12)$ MUFAL 6132-33, 8348, 11020, 14143-44, 14157-60, 14247, 14249.

Boana atlantica: $(\mathrm{n}=17)$ MUFAL 2500-04, 2696, 2698, 2705, 6729, 14145, 14181-82, 14198-99, 14206, 14253-54.

Boana crepitans: $(n=1)$ MUFAL 2353.

Boana semilineata: $(\mathrm{n}=7)$ MUFAL $14188,14190,14255-59$.

Dendropsophus branneri: $(\mathrm{n}=10)$ MUFAL 8463, 8465-66, 8468, 14170-71, 14176, 14178, 14263-64.

Dendropsophus elegans: $(\mathrm{n}=1)$ MUFAL 2912.

Dendropsophus haddadi: ( $\mathrm{n}=5$ ) MUFAL 8799, 11014, 14211, 14213, 14232.

Dendropsophus minutus: $(\mathrm{n}=4)$ MUFAL 5508, 5516, 5517, 5518 .

Dendropsophus soaresi: $(\mathrm{n}=3)$ MUFAL 8740, 8741, 9618 .

Ololygon skuki: $(\mathrm{n}=1)$ MUFAL 12390.

Phyllodytes edelmoi: $(n=7)$ MUFAL 14155-56, 14167, 14231, 14243, 14248.

Scinax auratus: $(n=4)$ MUFAL 14177, 14200, 14270-71.

Scinax eurydice: $(n=4)$ MUFAL 14185-86, 14197, 14201.

Scinax fuscovarius: Adults $(n=1)$ MUFAL 8759

Scinax nebulosus: $(\mathrm{n}=14)$ MUFAL 6407-09, 6413-15, 11868-70, 14142, 14165, 14175, 14214, 14261.

Scinax x-signatus: $(\mathrm{n}=16)$ MUFAL 2424-29, 14164, 14166, 14173, 14202-03, 14205, 14272-75.

Trachycephalus mesophaeus: $(\mathrm{n}=6)$ MUFAL 1982, 2117, 2151, 2193, 7362, 7363.

\section{LEPTODACTYLIDAE}

Adenomera hylaedactyla: $(\mathrm{n}=12)$ MUFAL 3307, 3315, 3321-24, 3590, 3592, 4194, 14169, 14174, 14245.

Leptodactylus fuscus: $(\mathrm{n}=11)$ MUFAL 2476-77, 8671, 14184, 14187, 14276-81.

Leptodactylus macrosternum: $(\mathrm{n}=3)$ MUFAL 14153-54, 14265.

Leptodactylus mystaceus: ( $\mathrm{n}=7$ ) MUFAL 4192, 8764, 14149, 14193-94, 14204, 14246.

Leptodactylus natalensis: $(\mathrm{n}=15)$ MUFAL 2689-90, 6441-44, 6446-49, 14147, 14161-62, 14229, 14241.

Leptodactylus troglodytes: $(n=1)$ MUFAL 2946.

Leptodactylus vastus: $(\mathrm{n}=6)$ MUFAL 14150, 14163, 14225, 14233-34, 14236.

Physalaemus cuvieri: ( $\mathrm{n}=13$ ) MUFAL 3125, 3435, 3469, 3473, 3478, 3586, 3955, 3997, 4607, 6450, 14146, 14196, 14207.

Pseudopaludicola mystacalis: $(\mathrm{n}=7)$ MUFAL 2513-16, 14267-69.

\section{MICROHYLIDAE}

Chiasmocleis alagoana: $(\mathrm{n}=8)$ MUFAL 10963-67, 10969, 11274-75.

Dermatonotus muelleri: $(\mathrm{n}=12)$ MUFAL 2567, 3316, 3392, 3398, 3439, 3447, 3476, 3585, 3591; 3938, 4007, 4008.

\section{ODONTOPHRYNIDAE}

Macrogenioglottus alipioi: $(\mathrm{n}=20)$ MUFAL 5483-84, 5493-94, 8165-66, 10940-42, 14151-52, 14208, 14230, 14235, 14237-40, 14244.

\section{PHYLLOMEDUSIDAE}

Hylomantis granulosa: $(\mathrm{n}=5)$ MUFAL 8486, 8798, 12106, 14210, 14215, 14252.

Pithecopus gonzagai: $(\mathrm{n}=1)$ MUFAL 14251. 